\title{
Colonic conduit prolapse after transanal total mesorectal excision (taTME)
}

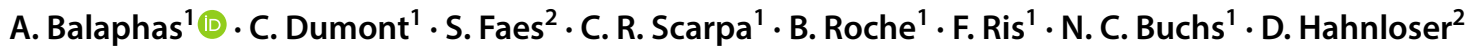

Received: 22 March 2018 / Accepted: 9 May 2018 / Published online: 24 May 2018

๑) Springer International Publishing AG, part of Springer Nature 2018

Sir,

Observational studies have demonstrated the safety of taTME. As it offers "new" anatomy to the surgeon, a recent expert consensus recommended formal training before performing such a procedure (including course and coaching) [1]. But even with proper preparation, this new technique could lead to complications that are unusual and rarely seen after standard laparoscopic or open total mesorectal excision (TME).

We report here four cases of colonic conduit prolapse after taTME. Patients were identified during outpatient follow-up. They were all men (A, B, C, D) and were, respectively, 66, 65, 76 and 60 years old at surgery. All of them had taTME for low rectal cancer (Table 1). Patients $\mathrm{C}$ and $\mathrm{D}$ underwent a total intersphincteric resection, whereas in patients $\mathrm{A}$ and $\mathrm{B}$, the intersphincteric resection was partial and subtotal, respectively. All anastomoses were handsewn and protected with an ileostomy. In all patients, TME was complete, but two had positive anterior circumferential margins and distal margins, respectively. The latter refused abdominal perineal amputation. No recurrence of disease was observed after a follow-up of 282, 422, 606, and 1019 days.

Colonic conduit prolapse was observed 44, 79, 243, and 958 days after taTME. Patients A, B, and C had transanal repair with colonic resection, new hand-sewn anastomosis and levatorplasty (Fig. 1) and patient $\mathrm{C}$ had an additional overlapping sphincteroplasty as part of the procedure. Patient D is currently awaiting surgery. Patients B and C

A. Balaphas

alexandre.balaphas@hcuge.ch

1 Division of Visceral Surgery, Department of Surgery, Geneva University Hospitals, 4, Rue Gabrielle-Perret-Gentil, 1211 Geneva, Switzerland

2 Department of Visceral Surgery, Lausanne University Hospital (CHUV), Lausanne, Switzerland had two recurrences of prolapse which were managed by the same technique as primary repair and for patient $\mathrm{C}$, a biologic mesh was added to retain the posterior colonic conduit in the pelvis. The same patient developed a posterior ectropion of rectal mucosa. This was managed by semi-circular resection of the anastomosis, post-anal repair, reanastomosis, and Sarafoff incision. This consists of an incision deep to the subcutaneous tissue, along $2 / 3$ of the anal circumference, $2 \mathrm{~cm}$ away from the anal verge, which releases the ectropion. A few months after this last surgery, patient $\mathrm{C}$ developed a third recurrence of colonic conduit prolapse and is currently awaiting further surgery. Patients A and B are recurrencefree after 216 and 100 days of follow-up with Wexner scores of 24/24 and 5/24 and Low Anterior Resection Scores of $31 / 42$ and 24/42, respectively.

Colonic conduit prolapse is a rare complication and has been reported after very low rectal surgery with intersphincteric resection and after transanal abdominal transanal (TATA) proctosigmoidectomy. Based on their experience, Chau et al. calculated that prolapse of the colonic conduit had occurred in $7 \%$ of patients with partial resection of the internal anal sphincter (IAS) and $14 \%$ of patients with subtotal or total IAS resection [2]. In Geneva and Lausanne University Hospitals, we performed 25 and 13 taTME, respectively, which bring the pooled rate of colonic conduit prolapse to $10.5 \%$.

In a case-matched analysis comparing taTME to laparoscopic TME, Marks et al. mentioned one case of colonic conduit prolapse in the taTME group [3]. In early 2018, the same group presented a cohort study on colonic conduit prolapse, regrouping different kinds of transanal proctosigmoidectomy procedures [4]. Surprisingly, a majority of colonic conduit prolapse was found in women $(9.5 \%$ in women versus $2.5 \%$ in men). The rate of colonic conduit prolapse for each surgical technique was reported, but variables of interest were pooled, and the study did not specifically assess taTME. To the best of our knowledge, we report 
Table 1 Patients treated with taTME: demographics, perioperative characteristics and long-term issues

\begin{tabular}{|c|c|c|c|c|}
\hline \multicolumn{5}{|l|}{ Cases characteristics } \\
\hline & Patient A & Patient B & Patient $\mathrm{C}$ & Patient D \\
\hline BMI $\left[\mathrm{kg} / \mathrm{m}^{2}\right]$ & 24.3 & 26.8 & 23.2 & 21.3 \\
\hline ASA classification & 2 & 1 & 3 & 2 \\
\hline Dose of radiotherapy [Gy] & 0 & 50.4 & 50.4 & 25 \\
\hline $\begin{array}{l}\text { Tumor distance to anal } \\
\text { verge }[\mathrm{cm}]\end{array}$ & 2 & 2 & 3 & 2.8 \\
\hline $\begin{array}{l}\text { Anastomotic height from } \\
\text { anal verge }[\mathrm{cm}]\end{array}$ & 1 & 1 & 1 & 1 \\
\hline Anastomosis type & $\begin{array}{l}\text { Hand-sewn end-to-end } \\
\text { coloanal anastomosis }\end{array}$ & $\begin{array}{l}\text { Hand-sewn end-to-end } \\
\text { coloanal anastomosis }\end{array}$ & $\begin{array}{l}\text { Hand-sewn side-to-end } \\
\text { coloanal anastomosis }\end{array}$ & $\begin{array}{r}\text { Hand-sewn side-to-end } \\
\text { coloanal anastomosis }\end{array}$ \\
\hline TNM stage & $\begin{array}{l}\text { pT3 pN1a L1 V1 Pn1 G2 } \\
\text { R1 }\end{array}$ & $\begin{array}{l}\text { ypT1 ypN0 L0 V0 Pn0 } \\
\text { G2 R1 }\end{array}$ & $\begin{array}{l}\text { ypT2 ypN0 L0 V0 Pn0 } \\
\text { G2R0 }\end{array}$ & $\begin{array}{l}\text { ypT2 ypN0 L0 V0 Pn0 } \\
\text { G2R0 }\end{array}$ \\
\hline $\begin{array}{l}\text { Positive lymph nodes [ } n / \\
\text { total] }\end{array}$ & $1 / 16$ & $0 / 19$ & $0 / 12$ & $0 / 10$ \\
\hline TME quality & Complete & Complete & Complete & Complete \\
\hline Rectal cancer recurrence & No & No & No & No \\
\hline $\begin{array}{l}\text { Maximum } 30 \text { days Clavien- } \\
\text { Dindo complication grade }\end{array}$ & 2 & 0 & 1 & 1 \\
\hline TOT, $\min$ & 299 & 262 & 480 & 411 \\
\hline LOS, days & 14 & 5 & 12 & 12 \\
\hline $\begin{array}{l}\text { Time from taTME to } \\
\text { colonic conduit prolapse, } \\
\text { days }\end{array}$ & 44 & 79 & 243 & 958 \\
\hline $\begin{array}{l}\text { Number of recurrences of } \\
\text { colonic conduit prolapse }\end{array}$ & 0 & 2 & $3^{\mathrm{a}}$ & na \\
\hline
\end{tabular}

$B M I$ Body mass index, ASA American Society of Anesthesiologists, Gy gray, AV anal verge, TNM TNM classification of malignant tumor, TME total mesolectal excision, TOT total operative time, LOS length of stay, na not applicable

${ }^{a}$ Including rectal mucosa ectropion

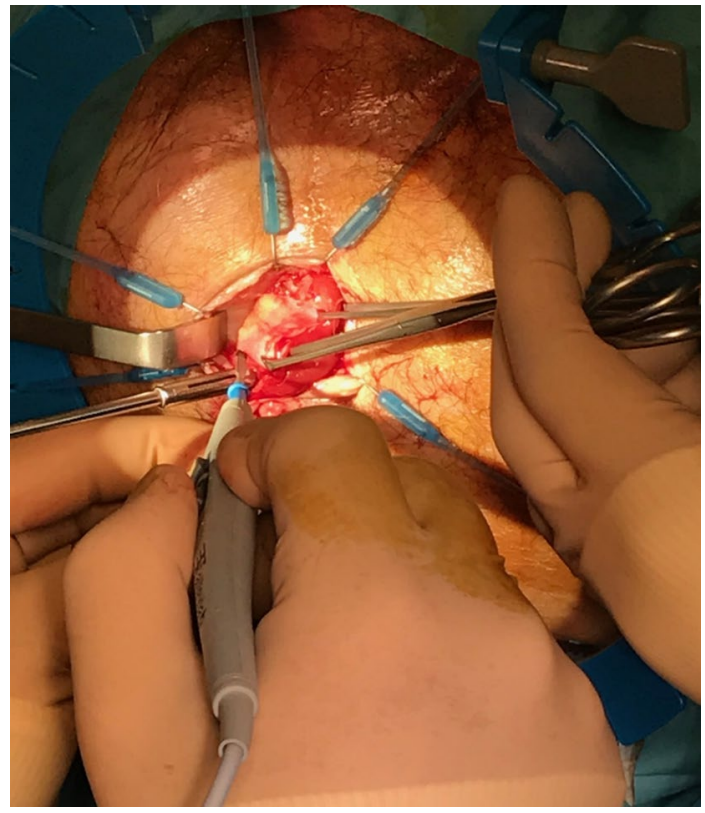

Fig. 1 Resection of coloanal anastomosis after colonic conduit prolapse here the first series of exclusively taTME-related colonic conduit prolapse.

The physiopathology of colonic conduit prolapse is not clearly understood. IAS contributes to a significant part of resting anal tone. Harmston et al. demonstrated an association between the grade of internal rectal prolapse (Oxford classification) and anal mean maximal resting pressure measured during manometry (which corresponds to IAS tone) [5]. This association explains the symptom of anal incontinence that patients with internal rectal prolapse may have. However, this study did not assess whether decreased IAS tone may favour rectal prolapse, and the relationship between IAS weakness and rectal prolapse is still unclear. During low taTME, intersphincteric resection is performed and the IAS is partially or totally removed. This might be implicated in colonic conduit prolapse.

During reconstruction of the anastomosis, we were surprised to find few adhesions around the anastomosis and the colonic conduit in all patients. Indeed, taTME allows distal dissection in an avascular plane that is perhaps not prone to form adhesions which should normally have fixed the colonic conduit in place and prevented prolapse. 
Colonic conduit prolapse after low anastomosis seems to have a female predominance. In this series, all the patients were men, which either might reflect a predominance of men selected for taTME, or perhaps differences in pathophysiology between women and men.

Due to the functional impairment that may be caused by this complication, more evidence is needed to assess the frequency and impact of colonic conduit prolapse in low rectal cancer surgery.

\section{Compliance with ethical standards}

Conflict of interest The authors declare that they have no conflict of interest.

Ethical approval Patients data were collected and handled in accordance with the institutional ethical standard and the national regulation on data protection.

Informed consent Informed consent was obtained from all individual participants.

\section{References}

1. Adamina M, Buchs NC, Penna M, Hompes R, St. Gallen Colorectal Consensus Expert Group (2018) St.Gallen consensus on safe implementation of transanal total mesorectal excision. Surg Endosc 32:1091-1103

2. Chau A, Frasson M, Debove C, Maggiori L, Panis Y (2016) Colonic prolapse after intersphincteric resection for very low rectal cancer: a report of 12 cases. Tech Coloproctol 20(10):701-705

3. Marks JH, Montenegro GA, Salem JF, Shields MV, Marks GJ (2016) Transanal TATA/TME: a case-matched study of taTME versus laparoscopic TME surgery for rectal cancer. Tech Coloproctol 20(7):467-473

4. Guraieb-Trueba M, Helber AR, Marks JH (2018) Full-thickness neorectal prolapse after transanal transabdominal proctosigmoidectomy for low rectal cancer: a cohort study. Colorectal Dis. https ://doi.org/10.1111/codi.14030

5. Harmston C, Jones OM, Cunningham C, Lindsey I (2011) The relationship between internal rectal prolapse and internal anal sphincter function. Colorectal Dis 13(7):791-795 